\title{
Electrocardiogram LOINC Code
}

National Cancer Institute

\section{Source}

National Cancer Institute. Electrocardiogram LOINC Code. NCI Thesaurus. Code C83261.

The LOINC code of an electrocardiogram. 